2016-07-30

\title{
Global Community Partnership Research
}

\author{
Lynch, TJ
}

http://hdl.handle.net/10026.1/6375

10.1007/978-3-319-31667-3_5

Springer International Publishing

All content in PEARL is protected by copyright law. Author manuscripts are made available in accordance with publisher policies. Please cite only the published version using the details provided on the item record or document. In the absence of an open licence (e.g. Creative Commons), permissions for further reuse of content should be sought from the publisher or author. 


\title{
Global Community Partnership Research
}

\begin{abstract}
This chapter investigates a successful teacher education programme in the UK, awarded 'Outstanding' by England's Office for Standards in Education, Children's Services and Skills. Furthermore, the success of the programme was explicitly contributed by established partnerships with nearby schools. This course, at the time, was not offered within Australia. This study offered valuable insight into a successful primary teacher education programme/course, illustrated good practice, and subsequently, offered possible improvements to the preparation of preservice primary teachers in Gippsland, Australia.
\end{abstract}

This research investigates a successful teacher education programme in the UK; awarded 'Outstanding' by England's Office for Standards in Education, Children's Services and Skills (Ofsted). Furthermore, the success of the programme was explicitly contributed by established partnerships with nearby schools. The Bachelor of Education (Hons) Primary (PE) course was specifically designed to develop generalist primary classroom teachers with a specialisation in PE. This course, at the time, was not offered within Australia; however, national curriculum reform has ignited a renewed interest in the health and wellbeing of children beginning in the early years of education, and subsequently, course designs that enable this. A qualitative, interpretive study using a case study methodology was

(C) The Editor(s) (if applicable) and The Author(s) 2016

T. Lynch, The Future of Health, Wellbeing and Physical Education, DOI 10.1007/978-3-319-31667-3_5 
adopted. Methods engaged included semi-structured interviews, reflective journals, observations, and document analysis, and participants included all course lecturers. This study offered valuable insight into a successful primary teacher education programme/course, illustrated good practice, and subsequently, offered possible improvements to the preparation of pre-service primary teachers in Gippsland, Australia.

\section{INTRODUCTION}

It is argued that the key learning area for children's health and wellbeing, $\mathrm{HPE}$, be a priority in the recent Australian national curriculum reform:

to provide ongoing, developmentally appropriate opportunities for students to practise and apply the knowledge, understanding and skills necessary to maintain and enhance their own and others' health and wellbeing. (ACARA 2012 , p. 4)

The implementation of HPE from the early years of primary school increases the likelihood of holistic lifelong health and wellbeing. An issue greatly valued by governments responsible for costs involved with wellness of citizens, the influence of hypokinetic diseases, and the strong connection physical activity has with optimal health and quality of life (Corbin et al. 2011; Robbins et al. 2011; Mackenroth 2004; Howard 2004). The purpose of the HPE learning area is to "offer experiential learning, with a curriculum that is relevant, engaging, contemporary, physically active, enjoyable and developmentally appropriate" (ACARA 2012, p. 2). However, the HPE learning area has had a history of barriers that have impeded quality delivery within all Australian Primary schools, which Sloan suggests has also existed in schools internationally (2010).

'In-house' discussions of crisis at HPE conferences and in journals 20 years ago led to a Senate Inquiry (Commonwealth of Australia 1992) into the state of HPE within Australian Education systems. The 'crisis' was experienced at an international level also (Dinan-Thompson 2009). The findings in the report by the Senate Standing Committee on Environment, Recreation and the Arts (Commonwealth of Australia 1992) confirmed the 'in-house' discussions of crisis (Dinan-Thompson 2009). The Senate Inquiry found that there was in fact a decline in the opportunities for quality HPE in Australian schools, although paradoxically there was unanimous support for the learning area. The problems were mainly with resources and the time allocation to the key learning area which resulted 


\section{REFERENCES}

Anderson, G. (1990). Fundamentals of educational research. London: The Falmer Press.

Anfara, V. A., Jr., Brown, K. M., \& Mangione, T. L. (2002). Qualitative analysis on stage: Making the research process more public. Educational Researcher, 31(7), 28-38.

Australian Council for Health, Physical Education and Recreation (ACHPER-WA Branch). (1999). Planning for action: Why teach physical education? Claremont, WA: ACHPER.

Australian Council for Health, Physical Education and Recreation (ACHPER). (2011). ACHPER supports AFL statement on need to strengthen PE and sport in primary schools. Retrieved from http://www.achper.org.au/_files/f/27583/ ACHPER\%20Media\%20Release\%2027\%2005\%2011.pdf

Australian Curriculum, Assessment and Reporting Authority. (2010). The shape of the Australian curriculum version 2.0. Sydney, NSW: ACARA.

Australian Curriculum, Assessment and Reporting Authority. (2012). Draft shape of the Australian curriculum: Health and physical education. Retrieved from http://www.acara.edu.au/hpe.html

Branta, C., Haubenstricker, J., \& Seefeldt, V. (1984). Age changes in motor skills during childhood and adolescence. Exercise and Sport Sciences Reviews, 12, 467-520.

Charon, J. M. (1998). Symbolic interactionism: An introduction, an interpretation, an integration. Englewood Cliffs, NJ: Prentice Hall.

Commonwealth of Australia. (1992). Physical and sport education-A report by the senate standing committee on environment, recreation and the arts. Canberra, ACT: Senate Printing Unit.

Corbin, C., Welk, G., Corbin, W., \& Welk, K. (2011). Concepts of fitness and wellness (9th ed.). New York: McGraw Hill.

Dinan-Thompson, M. (2009). Health and physical education: Issues for curriculum in Australia and New Zealand. South Melbourne, VIC: Oxford University Press.

Espenschade, A. S., \& Eckert, H. M. (1980). Motor development (2nd ed.). Sydney, NSW: Merrill.

Faulkner, G., Dwyer, J., Irving, H., Allison, K., Adlaf, E., \& Goodman, J. (2008). Specialist or nonspecialist physical education teachers in Ontario elementary schools: Examining differences in opportunities for physical activity. Alberta Journal of Educational Research, 54(4), 407-419.

Glesne, C. (1999). Becoming qualitative researchers: An introduction. Sydney, NSW: Addison Wesley Longman.

Howard, J. (2004, June 29). Building a healthy, active Australia. Transcript of the launch by Prime Minister, John Howard. Launceston, Tasmania. Retrieved 
January 7, 2005, from Building a Healthy, Active Australia Launch Launceston, Tasmania Web site: www.pm.gov.au/news/speeches/speech961.html

Lynch, T. (2005). An evaluation of school responses to the introduction of the Queensland 1999 health and physical education (HPE) syllabus and policy developments in three Brisbane Catholic primary schools (Doctoral thesis, ACU National, Australia). Retrieved from http://dlibrary.acu.edu.au/digitaltheses / public/adt-acuvp96.04092006/02whole.pdf

Lynch, T. (2007). What has changed since the 1992 Senate inquiry into physical and sport education? An Evaluation of school responses within three Brisbane Catholic Education (BCE) primary schools. Australian Council for Health and Physical Education and Recreation (ACHPER) Healthy Lifestyles Journal, 54(1), 16-23.

Lynch, T. (2008). Comparison of Health and Physical Education policies with practices: An evaluation of school responses within three Brisbane Catholic Education (BCE) primary schools (2005). The ICHPER-SD Journal of Research in Health, Physical Education, Recreation Sport and Dance, 3(2), 8-18.

Lynch, T. (2013a). Exploring religious education and health and physical education key learning area connections in primary schools. The International Journal of Humanities Education, 10(2), 11-23.

Lynch, T. (2013b). Health and physical education (HPE) teachers in primary schools: supplementing the debate. Australian Council for Health, Physical Education and Recreation (ACHPER) Active and Healthy Magazine, 20(3/4), 10-12.

Lynch, T. (2013c). Summary report of key findings for Australian Government primary schools. How are primary Education, Health and Physical education(HPE) teacher's best prepared? Retrieved from http://www.aitsl.edu.au/docs/defaultsource/default-document-library/lynch_2013_preparation_of_primary_ health _.physical_education_teachers.pdf?sfvrsn=4

Lynch, T. (2014). Swimming education in Australian society. The International Journal of Sport and Society, 3(4), 197-207.

Lynch, T. (2015a). Australian aquatic curriculum reform: treading water carefully? International Journal of Aquatic Research and Education, 9(2), 201-213. http://dx.doi.org/10.1123/ijare.2015-0005

Lynch, T. (2015b). Health and physical education (HPE): Implementation in primary schools. International Journal of Educational Research, 70 (c), 88-100. doi: $10.1016 /$ j.ijer.2015.02.003

Lynch, T. (2015d). Investigating children's spiritual experiences through the health and physical education learning area in Australian schools. Journal of Religion and Health, 54(1), doi:10.1007/s10943-013-9802-2.

Lynch, T. (2015e). Teacher education physical education: in search of a hybrid space. Cogent Education, 2(1), 1027085 doi: 10.1080/2331186X.2015. 1027085 
Mackenroth, T. (2004, June 11). Public letter from the deputy premier, treasurer and minister for sport. Brisbane, QLD: Queensland Government Printer.

Merriam, S. (1998). Qualitative research and case study applications in education: Revised and expanded from case study research in education. San Francisco, CA: Jossey-Bass.

Moore, D. (1994). The challenges for sport and physical education in schools. ACHPER Healthy Lifestyles Journal, 41(1/143), 23-28.

Morgan, P. (2008). Teacher perceptions of physical education in the primary school: Attitudes, values and curriculum preferences. Physical Educator, 65(1), 46-56.

Neuman, W. (2000). Social research methods: Qualitative and quantitative approaches. Sydney, NSW: Allyn and Bacon.

Patton, M. Q. (1990). Qualitative evaluation and research methods. London: Sage.

Raitakari, O. T., Porkka, K. V. K., Taimela, S., Telama, R., Rasanen, L., \& Viikari, J. S. A. (1994). Effects of persistent physical activity and inactivity on coronary risk factors in children and young adults. American Journal of Epidemiology, 140, 195-205.

Robbins, G., Powers, D., \& Burgess, S. (2011). A wellness way of life (9th ed.). New York: McGraw Hill.

Sloan, S. (2010). The continuing development of primary sector physical education: Working together to raise quality of provision. European Physical Education Review, 16(3), 267-281.

Stake, E. (1994). Handbook of qualitative research. Thousand Oaks, CA: Sage.

Tinning, R., Kirk, D., Evans, J., \& Glover, S. (1994). School physical education: A crisis of meaning. Changing Education, 1(2), 13-15.

Webster, P. J. (2001). Teachers' perceptions of physical education within the k-6 personal development, health and physical education key learning area (Theses, University of Woollongong). Abstract retrieved June 28, 2004, from Informit database.

Wellington, J. (2000). Educational research: Contemporary issues and practical approaches. London: Continuum. 